\title{
An Investigation of State Superintendents in the United States: Ethical Leadership Perspectives, State Leader Demographics, and State Education Characteristics
}

\author{
By Denver J. Fowler* \\ Raymonnesha Edwards ${ }^{\dagger}$ \\ Hsien-Yuan $\mathrm{Hsu}^{+}$
}

\begin{abstract}
The purpose of this study was to investigate the ethical leadership perspectives of state superintendents across the United States, including the District of Columbia, and the Department of Defense. Secondly, the researchers examined to what extent the ethical leadership perspectives of state superintendents were correlated with school leader demographics. Furthermore, the researchers examined to what extent the ethical leadership perspectives of the state superintendents were correlated with state education characteristics. Included in this survey were the Ethical Leadership Scale (ELS) and Social Desirability Scale (SDS). The ELS was used to measure the ethical leadership perspectives of superintendents in the study. The SDS was used to measure the socially desirable response tendencies of superintendents in the study. Additionally, the researchers collected self-reported state leader demographics and state education characteristics. The survey was sent to 38 state superintendents in the United States. A correlation analysis was used to analyze the data. This analysis was used to determine the correlation between the superintendents' ethical leadership perspectives and the self-reported state leader demographics and state education characteristics. Furthermore, the correlation analysis was used to identify which variables (state leader demographics and state education characteristics) have the strongest predictive relationship with the ethical leadership perspectives of the superintendents in the study.
\end{abstract}

Keywords: State Superintendent, Ethical Leadership Perspectives, United States, State Leader Demographics, State Education Characteristics.

\section{Introduction}

\section{Background of the Study}

Since the launching of Sputnik by Russia in 1957, America has pushed for reforms in education to raise student achievement in comparison with other nations, as it appeared to the general public that the United States was lacking

\footnotetext{
*Assistant Professor, Educational Leadership and Policy Studies, California State University, Sacramento, USA.

${ }^{\dagger}$ Ronald E. McNair Scholar, The University of Mississippi, USA.

${ }^{+}$Assistant Professor, Educational Research, The University of Texas, Health Science Center at Houston, USA.
} 
in the accumulation and production of knowledge. According to Education Week's Quality Counts 2016 report, the United States overall score for education is a $\mathrm{C}$ with an average of $74.4 \%$. Additionally, the report provided individual letter grades for each state with the lowest grade being a D (65.2) for the State of Nevada and the highest grade a B (86.8) for the State of Massachusetts. Although the United States once led the way in educationfrom a global standpoint, today, many believethe United States has fallen behind other countries around the globe. In fact, the world education rankings rank the United States twelfth. With such facts made known, tremendous pressure has been placed on those in power to create policies aimed to correct these steadily rising issues with regards to what many perceive as our declining quality of education in the United States.

Reforms put in place by former President of the United States, George W. Bush (No Child Left Behind) and current President Barack Obama (Race to the Top), were efforts created to improve the education systems here in America. However, state superintendents are the individuals who examine the needs of education in their respective states, and decide what is best for education in their states with regards to the initiatives, policies, and reforms adopted (Bon, 2012). Therefore, as state superintendents are charged with making such decisions with regards to their state's education systems, state superintendents often play a major role in the effectiveness of their schools and the achievement of their students throughout their respective states (Gamson, 2004).

\section{Statement of the Problem}

Restated, the goal for this research study was to: 1 . investigate the ethical leadership perspectives of the state superintendents in the United States; 2. to identify whether ethical leadership perspectives of state superintendents in the United States were correlated with state education characteristics; and 3. to determine if the ethical leadership perspectives of state superintendents in the United States were correlated with leader demographics.

Each day school leaders are faced with difficult dilemmas that calls for them to act quickly, but in a just manner (Noppe, Sheng, Webb, \& Yager, 2013). Yet, in accordance with making such decisions, there is also a call on the character based on the school leader's judgment (Jacobs \& Kritsonis, 2007). This call on character is a focus of all stakeholders including students, parents, staff, and community members, mainly because as school leaders make decisions, their morals should be just as involved with the rational thinking part of the problem. That is, decisions should be made morally and ethically with regards to the best interest of their aforementioned stakeholders. However, if there is compromise of one's core beliefs without any rationale other than the pressure of society and the satisfying thereof, then a major leader character flaw is in the midst. According to Jacobs and Kritsonis (2007), "If school leaders compromise, they are not leading" (p. 6). In spite of, such flaws should not exist as often as they do in any leadership, but perhaps especially in the education setting (Jacobs \& Kritsonis, 2007). Yes, society indeed plays a key role in giving insight to areas of change, however, decisions by educational leaders should not be based solely 
on what society believes or wants, as it takes the focus off of the reason they are school leaders. That is, to lead and create an environment appropriate for the growth and learning of all students (Jacobs \& Kritsonis 2007; Bon, 2012).

Therefore, as school leaders, the incorporation of ethical leadership within their daily responsibilities is a must. Ethical leadership embodies ideals that any person in a leadership position should not neglect (Gamson, 2004). For state superintendents, such practices are essential when it comes to the policies or reforms that are brought forth to be implemented in their respective state. As pressure mounts from society, policy makers, other leaders, stakeholders, and in general, a need for change, school leaders must not be neglectful in their use of "practitioner-based ethic to critique" (Gamson, 2004). The ethic of critique as taken from Starratt (1991) and suggests the routine practice of leaders should include a constant reflection on the current policies and procedures in order to identify any injustices. From this one concept alone, the necessity for school leaders to actively practice ethical leadership is just one (of many) important means to achieve success in schools across the United States.

\section{Research Questions}

In investigating the ethical leadership perspectives of state superintendents in the United States, District of Columbia, and the Department of Defense, and whether these perspectives vary according to state leader demographics and state education characteristics, this study will answer the following questions:

1. What are the ethical leadership perspectives of the state superintendents in the United States?

2. To what extent are the ethical leadership perspectives of state superintenddents in the United States correlated with state leader demographics?

3. To what extent are the ethical leadership perspectives of state superintenddents in the United States correlated with state education characteristics?

\section{Significance of the Study}

This study is significant for multiple reasons. State superintendents often set the tone for the environment and atmosphere of the states they preside over. Therefore, in having a role that affects multiple people's lives, including children, it is important to have a set of ethical principles to aid in one's ability to lead effectively and to produce positive outcomes (Noppe, Sheng, Webb, \& Yager, 2013). This research was focused on what is correlated with the ethical leadership perspectives of state superintendents in the United States, including the District of Columbia and the Department of Defense.

"Superintendents universally are faced with problems or dilemmas that challenge their leadership literally on a daily basis, and they must draw upon well-developed skills to make decisions or solve problems in a timely, appropriate, and responsible fashion" (Noppe, Sheng, Webb, \& Yager, 2013, p. 116). As reported, "well-developed skills", that is, partaking in the use of ethical leadership 
is not an act to be done every once in a while or when difficult situations arise. However, it should be daily practice as to become a way of life and leading. Through this study of the ethical leadership perspectives of state superintendents, and how these perspectives may be correlated with state leader demographics and state education characteristics, the researchers hope to gain more insightful information as it relates to the possible direct connection to both school success and student achievement, perhaps especially as it pertains to ethical leadership perspectives.

\section{Delimitations and Limitations of the Study}

The results of this study will be considered in view of relevant delimitations and limitations as described below.

Delimitations. The study included 38 out of 52 state superintendents in the United States including the District of Columbia and the Department of Defense. There are many state education characteristics and state leader demographics that could have been chosen for this study. Based on the extant literature (Fowler, 2014a; Fowler \& Johnson, 2014), the following state education characteristics were chosen for this study: 1 . the total state enrollment size; 2 . the number of district superintendents in the state; 3 . the total annual budget for education in the state; 4. the majority of school district locale (i.e., Urban, Suburban, Rural) in the state; and 5. the overall state rank (i.e., grade, score, and rank) according to the 2016 Education Week's Quality Counts report. The state leader demographics for this study are defined as: 1. the state superintendent's years of experience as a state superintendent/ commissioner of education; 2 . whether they were an appointed or elected state superintendent/commissioner of education; 3 . the state superintendent's years of experience as a superintendent, assistant superintendent, principal, assistant principal, athletic director, and/or dean of students; 4 . the gender of the state superintendent; 5 . the race of the state superintendent; 6 . the current age of the state superintendent; 7 . the state superintendent's highest education degree obtained; 8 . the number of ethical leadership courses the state superintendent completed in his/her educational degree program; 9. the name of the educational institution where state superintendents completed their superintendent license program; 10. if the state superintendent completed any type of mentoring program/experience as part of their superintendent license program; 11. if the superintendent completed and/or was part of any type of ethics training in-service and/or professional development outside of the required coursework for their superintendent license program; 12. estimated number of ethics training in-service and/or professional development outside of the required coursework for their superintendent license program; 13. the professional organizations in which the state superintendent has been actively involved during the last five to ten years; and 14. the subject area(s) and grade levels (if any) in which the state superintendent is licensed to teach.

Limitations. The study utilized an electronically emailed survey instrument. 
This method increased the possibility of a low return rate because there is no guarantee that the surveys are completed. The fewer number of surveys completed, the greater the likelihood of biased sampling (Fowler, 2014a; Fowler, 2014b; Fowler \& Johnson, 2014). The researchers attempted to ensure an adequate completion rate by sending a reminder email to state superintendents who did not respond after week one. An additional reminder email was sent to state superintendents who did not respond after weeks two and three. The researchers hoped that because the ELS, SDS, and accompanying questions were relatively brief and easy to complete, respondents would take time to complete the survey. Additionally, the researchers believed respondents would value this research, and therefore be more inclined to respond.

Another possible limitation was the participant's willingness to reveal honest and accurate information about perceptions regarding their own ethical leadership perspectives, individual demographics, and key information regarding their respective state education characteristics. To account for the participant's willingness to reveal honest and accurate information about perceptions regarding their own ethical leadership perspectives, the researchers used the SDS in conjunction with the ELS to control for any socially desirable response tendencies. Additionally, to account for participant's willingness to report accurate information regarding individual demographics and key information regarding their respective state education characteristics, the researchers pledged to maintain the anonymity of the respondents. Nevertheless, the motivation of the respondents was difficult to establish. As with most survey research, without knowing how serious the respondents were in completing the survey, the validity of the responses could not be accurately analyzed (Sax, 1979).

Finally, the possible completion of the online survey by someone other than the state superintendent was a possibility. That is, as with most survey research, there was no sure way to know that the state superintendents themselves actually completed the survey. Unknowingly, the state superintendent may have had a secretary and/or assistant state superintendent complete the survey for them. Additionally, someone responsible for filtering the state superintendent's emails could potentially have completed the survey. The researcher attempted to minimize this by addressing this potential issue in the cover letter as well assending an email directly to the state superintendent.

\section{Operational Definitions}

The following terms are used in this research study:

Ethical Leadership Perspectives. Ethical Leadership Perspectives are defined as to how the state superintendents perceive or view their own ethical leadership as well as what they consider to be ethical conduct versus what is not. Essentially, it is what state superintendents theoretically believe is ethical leadership and normatively appropriate conduct and ethical behavior (Brown, Harrison, \& Trevino, 2005; Fowler, 2014a; Fowler \& Johnson, 2014). The Ethical Leadership Scale (ELS) was used in this study to determine the Ethical Leadership 
Perspectives of state superintendents.

Ethical Leadership. Ethical Leadership refers to the observable behavior of a leader rather than a theoretical perception of what ethical leadership is and/or response tendencies to the ELS (Brown, Harrison, \& Trevino, 2005; Fowler, 2014a; Fowler \& Johnson, 2014). Essentially, it is the act of doing what is right versus doing what is wrong. It is the demonstration of normatively appropriate conduct through behavior.

Social Desirability. Social Desirability refers to what an individual believes to be acceptable in social or interpersonal relations (Fischer \& Fick, 1993; Fowler, 2014a; Fowler \& Johnson, 2014). Essentially, it is what state superintendents believe is socially acceptable. The Social Desirability Scale (SDS) was used in this study to determine the Social Desirability of state superintendents, and more specifically, the socially desirable response tendencies of the superintendents in the study.

State Superintendent. Defined, the state superintendent is "the principal executive officer of the Department of Education, the Superintendent sits on Governor's Cabinet, the State Administrative Board, and acts as chair and a non-voting member of the State Board of Education. The Superintendent advises the Legislature on education policy and funding needs, as defined by the State Board of Education. The Superintendent is responsible for the implementation of bills passed by the Legislature and policies established by the State Board of Education. The Superintendent is a major spokesperson for education in the state. The Superintendent is the primary liaison to the United States Department of Education and other federal agencies, and also provides efficient and effective management of the Department's considerable state and federal resources" (MDE, 2016). Just as the title of the position varies among states such as State Superintendent of Education, State Superintendent of Schools, State Superintendent of Public Instruction, and Commissioner of Education, state superintendents are selected for their position in a variety of processes through either appointment or election.

\section{Literature Review}

\section{Introduction to Literature}

Due to often overwhelming responsibilities that come with being a state superintendent, ethics play a major role in an educational leader's overall effectiveness (Bon, 2012). Not only are there standards created by major educational leadership organizations that promote ethical leadership, in addition, there are researchers and scholars alike who have conducted research and written literature to support how critical it is to incorporate ethics into educational leadership (Fowler, 2014a; Fowler \& Johnson, 2014). Of the various duties 
performed by state superintendents, their main duty is to ensure that the schools in their state are meeting the educational needs of the students enrolled (Bon, 2012). However, some dilemmas or predicaments experienced by school leaders could cause a sway in the proper execution of their ethical and moral values in which they must decide between satisfying society members and the system, or the needs of students and staff throughout their respective state (Ehrich, Harris, Klenowski, Smeed, \& Spina, 2015).

\section{Ethics}

Society plays a substantial role in how individuals ethically conduct themselves. Dating back to the days of Socrates, it has been understood that "moral concepts are embodied in and are partially constitutive of forms of social life" (MacIntyre, 1998, p. 1). As we function in society, there are instances, and for some multiple instances, where we will stop and ponder whether the decision we have to make is correct or not. This is where ethics come in to play. If a situation arises, especially when it could directly or even indirectly affect another person, you have to take into account your perspectives and their best interest.

As Macintyre stated "moral concepts change as social life changes" (1998, p. 1). Historically, this is seen as the views of ethics in reference to Socrates and Aristotle somewhat differ. As Aristotle puts it, Socrates believed that "all the moral virtues were forms of knowledge; in such a way that when we knew what justice was, it followed that we would be just" (Macintyre, 1998, p. 21). Thus, if justice was not followed, presumably there was not an issue morally yet there lies a lack in intellect. Aristotle also critiques this thought of Socrates by stating "yet where moral virtue is concerned, the most important thing is not to know what it is, but how it arises; we do not wish to know what courage is, we wish to be courageous" (Macintyre, 1998, p. 22). Therefore, we do not wish just to know what is right, but we wish to be righteous or upright. In regards to Aristotle's view on ethics, he states, as taken from his book Nicomachean Ethics, that "Every craft and every inquiry, and similarly every action and project, seems to aim at some good; hence the good has been well defined as that at which everything aims" (Macintyre, 1998, p. 57). Aristotle portrays the aim as "good" not necessarily the actual action and outcome to be good. However, with those in power, there is no real way of knowing whether their intentions are aiming for good. Although as a school leader, the researchers contend, that the aim should always be what is best for students, and furthermore, that a school leaders aim and results should exude goodness at the very least, a majority of the time.

\section{Ethics in Leadership}

In regards to leadership, specifically educational leadership, ethics and law are at the forefront. Thus, "It is not surprising then that law and ethics have both emerged as key areas of focus in school administration programs" (Bon, 2012, p. 286). This is due to the fact that school leaders "confront a myriad of 
issues on a regular basis" (Noppe, Sheng, Webb, \& Yager, 2013, p. 103). Therefore, it is crucial that school leaders be prepared to deal with any quandary they may face, however, if lack of training or experience is present, an even greater dilemma is at hand. As "experience builds knowledge" and "knowledge informs practice" (Barton, 2013, p. 93).

Regarding law and ethics specifically, Bon (2013) also states that "education is not primarily a legal enterprise; rather, the protection of educational opportunities is also deeply rooted in ethical principles, values, beliefs, and moral obligations" (p. 286). Therefore, in order to ensure the quality of the education promised to be provided, ethics must be embedded into a leader's leadership characteristics. Nonetheless, some educational leaders experience moments of weakness when it comes to doing what is ethically professional, and in some cases, legal. For example, cheating scandals in regards to standardized testing has become all too prevalent. This "wider swath of teachers and principals crossing ethical boundaries" is brought on by "the high-stakes standardized testing required under the federal No Child Left Behind Law" (Schachter, 2011, p. 5052). As these tests are used to measure student achievement and school worthiness, some school leaders feel pressured to produce excellent results no matter the cause, and likewise, are willing to put their job on the line for such results (Schachter, 2011). These "[ethical] dilemmas are likely to pull leaders in a variety of directions as they struggle to meet the demands of the system on the one hand and the specific needs of the students and staff on the other" (Ehrich, Harris, Klenowski, Smeed, \& Spina, 2015, p. 200). However, participating in such actions such as cheating scandals involving standardized testing is "totally unethical and wrong" yet "we're probably going to see more of it as educators feel the pressure" (Schachter, 2011, p. 52). Yet, our school leaders should be "self-confident, rational thinkers who possess strong values and ethics", whose "character should not be questioned", and neither should they be "observers of acts that they know are foolish and do nothing about it" (Jacobs \& Kritsonis, 2007, p. 3).

\section{Ethical Leadership Perspectives and Superintendents}

Little or no research exists focusing on both the ethical leadership perspectives of superintendents and how they vary according to leader demographics and school district characteristics. Nevertheless, some extant literature and research does exist. Based on this extant literature and previous research studies, researchers found that ethical leadership perspectives varied according to superintendent leader demographics and school district characteristics (Fowler, 2014a; Fowler \& Johnson, 2014). Conversely, these studies were conducted with school district superintendents versus state superintendents. Nonetheless, the findings of these studies proved to be significant in that it was determined that the ethical leadership perspectives of superintendents did in fact vary according to school leader demographics (i.e., age, gender) and school district characteristics (i.e., highest educational degree obtained, student achievement).

As previously defined, ethical leadership refers to the observable behavior 
of a leader rather than a theoretical perception of what ethical leadership is and/or response tendencies to the Ethical Leadership Scale (ELS) used in this study (Brown, Harrison, \& Trevino, 2005; Fowler, 2014a; Fowler \& Johnson, 2014). Essentially, ethical leadership is the act of doing what is right versus doing what is wrong (Fowler, 2014, Fowler \& Johnson, 2014). While, ethical leadership perspectives are defined as to how the state superintendents perceive or view their own ethical leadership as well as what they consider to be ethical conduct versus what is not (Fowler, 2014a; Fowler \& Johnson, 2014). For all intents and purposes of this study, ethical leadership perspectives are what state superintendents theoretically believe is ethical leadership and normatively appropriate conduct and ethical behavior (Brown, Harrison, \& Trevino, 2005; Fowler, 2014a; Fowler \& Johnson, 2014). The ELS was used in this study to determine the ethical leadership perspectives of state superintendents.

Ethical leadership is "the demonstration of normatively appropriate conduct through personal actions and interpersonal relationships, and the promotion of such conduct to followers through two-way communication, reinforcement, and decision-making" (Brown, Harrison, \& Trevino, 2005, p. 120). Those in leadership positions are unique due to their influence, as "many leaders also control resources and are responsible for making important decisions about employees" (Fowler \& Johnson, 2014, p. 41). Yet, research and literature shows "that leaders, who are considerate of their followers and treat these followers with fairness, are considered to be ethical leaders" (Fowler \& Johnson, 2014, p. 41).

\section{State Superintendents}

The variable identified in this study is state superintendents in the United States (including the Department of Defense and District of Columbia). State superintendents usually serve a four-year term, and state superintendents in the United States can either be appointed or elected into their respective positions (District of Columbia is listed as "other", Russo, 2013). Currently there are 36 states that have state superintendents who are appointed by either their state's State Board of Education (i.e., Alabama, Alaska, Arkansas, Colorado, Connecticut, Florida, Hawaii, Illinois, Kansas, Kentucky, Louisiana, Maryland, Massachusetts, Michigan, Minnesota, Mississippi, Missouri, Nebraska, New York, Ohio, Rhode Island, Utah, and West Virginia) or their Governor (i.e., Delaware, Iowa, Maine, Minnesota, Nevada, New Hampshire, New Jersey, New Mexico, Oregon, Pennsylvania, Tennessee, Vermont, and Virginia). The other 14 state superintendents (i.e, Arizona, California, Georgia, Idaho, Indiana, Montana, North Carolina, North Dakota, Oklahoma, South Carolina, South Dakota, Washington, Wisconsin and Wyoming) are elected. Regardless of how the state superintendents are selected, one aspect shared across the board is the need for ethics. These is echoed in the standards used for accreditation of our nations educational leadership programs. According to the Professional Standards for Educational Leaders created by the National Policy Board for Educational Administration (2015), Standard 2 states that "Effective educational leaders act ethically and according to professional norms to promote each student's academic success and well-being". Additionally, 
the 2011 ELCC Building Level Standard 5.0 says that "a building-level education leader must know how to act with integrity, fairness, and engage in ethical practice. Observations by education experts affirm the central role that knowledge of reflective practices has for education leaders if they are to model principles of self-awareness and ethical behavior." Finally, a number of theoretical and practice focused commentaries have noted the critical need for education leaders to have knowledge of the moral and legal consequences of decision-making.

\section{Summary}

According to the extant literature, ethics and leadership are intimately intertwined. Not only are there standards created by major educational leadership organizations that promote ethical leadership, there are also researchers and scholars who have written literature to show how critical it is to incorporate ethics into educational leadership preparation programs. Therefore, ethics in regards to educational leadership, involves not only doing what is right or wrong, but it incorporates doing what is right, not wrong, for all stakeholders in which they lead, namely, students.

There was little to no extant research on ethical leadership perspectives of state superintendents, or furthermore, how these ethical leadership perspectives vary according to a state education characteristics and state leader demographics. However, the researchers hope that this particular study will further support the need to conduct more research on the subject matter, and determine how it affects other areas of leadership or leader's decision-making processes in the education setting.

\section{Methodology}

\section{Introduction}

This study focused on the ethical leadership perspectives of state superintendents in the United States, District of Columbia, and Department of Defense. Secondly, this study examined to what extent the ethical leadership perspectives of the state superintendents in the United States were correlated with state education characteristics. Additionally, this study examined to what extent the ethical leadership perspectives of state superintendents in the United States were correlated to state leader demographics.

Restated, the questions guiding this study were:

1. What are the ethical leadership perspectives of the state superintendents in the United States?

2. To what extent are the ethical leadership perspectives of state superintendents in the United States correlated with state leader demographics?

3. To what extentare the ethical leadership perspectives of state superintendents in the United States correlated with state education characteristics? 


\section{Research Design}

This research used an electronically emailed survey (See Appendix A) in order to collect data. The final version of the survey included 27 questions. A 10 item ELS (See Appendix A) and 10 item SDS (See Appendix A) were included as matrix questions within the survey using a matrix table and click button response. The ELS used a five-point Likert scale with click button responses. The SDS used a True or False with click button responses.

The ELS is comprised of 10 items descriptive of ethical leadership perspectives. Respondents reacted to each statement on a five-point Likert scale indicating the degree to which the statement reflects their own leadership perspectives. The results of the ELS were used to determine state superintendent ethical leadership perspectives across the United States including the District of Columbia and the Department of Defense. The ELS results were then compared to the leaders' self-reported data. This self-reported data included state education characteristics and state leader demographics.

Although no norms for scoring on the ELS have been developed, enough research has been conducted using the ELS to provide some general guidance and interpretation. On a five-point Likert scale response format, with three as the mid-point, we can consider scores above three to be evidence of positive ethical leadership perspectives and scores below three represent negative ethical leadership perspectives (Bowers, 2009; Brown, Trevino, \& Hartman, 2003; Brown, Harrison, \& Trevino, 2005; Brown \& Trevino, 2006; Fowler, 2014a; Fowler \& Johnson, 2014).

The SDS "short form" version of the Marlowe-Crowne Social Desirability Scale has been used successfully in several research studies and is a validated research instrument (Fischer \& Fick, 1993; Strahan \& Gerbasi, 1972). This 10item scale was used to measure state superintendents socially desirable response tendencies. Respondents reacted to each statement by selecting "True" or "False" as to whether the statement pertained to their own personality.

Scoring for the short form version of the SDS ranged from zero to 10. For each statement on the SDS, participants responded by indicating true or false. The participant received a point for responding to each statement in the "keyed" direction. The higher scores were indicative of greater social desirability. For example, items such as "I'm always willing to admit it when I make a mistake." and "I never resent being asked to return a favor." were keyed true. Whereas items such as "I like to gossip at times." and "I sometimes try to get even rather than forgive and forget." were keyed false. In scoring the SDS, participants received one point for each response keyed correctly. The correct response would be indicative of greater level of social desirability, that is, a higher level of socially desirable response tendencies of a given individual.

In addition to the ELS and SDS matrix questions, the final version of the survey included five accompanying questions directly related to state education characteristics, 14 questions directly related to state leader demographics, and six extended response questions. The final version of the survey was 27 questions. 
A total of 13 survey questions were "click button response", 13 questions were "open ended response", and one question utilized a drop down menu response.

There are 52 state superintendents in the United States including the District of Columbia and the Department of Defense. In attempting to retrieve the email addresses of all 52 state superintendents, only 38 were accessible. Therefore, a total of 38 surveys were electronically emailed. A cover letter (See Appendix A) was included with the survey. A reminder email was sent to those state superintendents who did not respond after week one. An additional reminder email was sent to those superintendents who did not respond after weeks two and three. A final "Thank You" email was sent to those superintendents who completed the survey at the conclusion of week three.

All data from the surveys were collected using Qualtrics, an online survey software program. In order to minimize the opportunity for collaboration among state superintendents, the researchers obtained responses within three weeks of the first electronic mailing of the surveys.

\section{Operational Definitions of the Variables}

As previously mentioned, Ethical Leadership Perspectives are defined as to how the state superintendents "perceive or view their own ethical leadership as well as what they consider to be ethical conduct versus what is not" (Fowler, 2014a, p. 75). Essentially, it is what state superintendents "theoretically believe is ethical leadership and normatively appropriate conduct and ethical behavior" (Brown, Harrison, \& Trevino, 2005; Fowler, 2014a, p. 75). The Ethical Leadership Scale (ELS) was used in this study to determine the Ethical Leadership Perspectives of state superintendents. Ethical Leadership refers to the observable behavior of a leader rather than a theoretical perception of what ethical leadership is and/or response tendencies to the ELS (Brown, Harrison, \& Trevino, 2005). "It is the act of doing what is right versus doing what is wrong. It is the demonstration of normatively appropriate conduct through behavior" (Fowler, 2014a). Social Desirability refers to what an individual believes to be acceptable in social or interpersonal relations (Fischer \& Fick, 1993). It is what state superintendents believe to be socially acceptable. The Social Desirability Scale (SDS) was used in this study to determine the socially desirable response tendencies of state superintendents. For this study, state education characteristics are defined as: 1. the total state enrollment size; 2 . the number of superintendents in state; 3. the total annual budget for education in state; 4. the majority of school district locale (i.e., Urban, Suburban, Rural); and the overall state rank (i.e., grade, score, and rank) according to the 2016 Education Week's Quality Counts report. The state leader demographics for this study are defined as: 1. the state superintendent's years of experience as a state superintendent/commissioner of education; 2. whether they were an appointed or elected state superintendent/ commissioner of education; 3 . the state superintendent's years of experience as a superintendent, assistant superintendent, principal, assistant principal, athletic director, and/or dean of students; 4 . the gender of the state superintendent; 5 . the race of the state superintendent; 6 . the current age of the state superintendent; 7 . 
the state superintendent's highest education degree obtained; 8. the number of ethical leadership courses the state superintendent completed in his/her educational degree program; 9 . the name of the educational institution where the state superintendent completed their superintendent license program; 10. if state superintendent completed any type of mentoring program/experience in their superintendent license program; 11 . if the superintendent completed and/or was part of any type of ethics training in-service and/or professional development outside of the required coursework for their superintendent license program; 12. estimated number of ethics training in-service and/or professional development outside of the required coursework for their superintendent license program; 13. the professional organizations in which the state superintendent has been actively involved during the last five to ten years; and 14. the subject area(s) and grade levels (if any) in which the state superintendent is licensed to teach .

\section{Instrumentation}

To measure the ethical leadership perspectives of the state superintendents in the United States, the Ethical Leadership Scale (ELS) developed by Brown, Trevino, and Harrison (2005) was utilized. See Appendix A for a copy of the ELS. The ELS has been used successfully in other studies on ethical leadership and is one of the only validated ethical leadership scales available for use. Brown, et al., "established validity by administering the instrument to 154 MBA students at a Midwestern research university and to 127 employees of a large, multilocation, financial services firm in the United States" (Bowers, 2009, p. 53). Internal reliability for the ethical leadership scale, as measured by Cronbach's Alpha $(\alpha=.92)$. Ethical leadership perspectives, as measured by the 10 items on the ELS, formed a coherent construct. Exploratory Factor Analysis (EFA) data was used to reduce the ELS from a 48-item scale to a 10-item scale. The ELS also demonstrated internal consistency (Study 2: $\alpha=.92$, Study 3: $\alpha=.91$, Study 5: $\alpha=.94)$. Additionally, "the internal reliability for the ELS, as measured by Cronbach's Alpha, was excellent" ( $\alpha=.92$ )" (Bowers, 2009, p. 53). The ELS reported to be a reliable scale that provides a comprehensive and rigorous assessment of an individual's perspective as it relates to their ethical leadership. In measuring the social desirability of state superintendents in the United States, the Social Desirability Scale (SDS) "short form" developed by Strahan and Gerbasi (1972) was used. See Appendix A for a copy of the SDS. The SDS is validated and has been used in previous studies to measure social desirability of individuals. Because of the practical difficulty with the original 33 item SDS (due to its length), "a number of short forms of the SDS have emerged" (Fischer \& Fick, 1993, p. 734). In a study by Fischer \& Fick (1993), the SDS "short form" used in this study proved to be the scale of choice. Fischer \& Fick (1993) wrote "It is a 10-item scale, one of the shortest in length. It has high internal consistency and is highly correlated with the standard 33-item form originally developed by Crowne and Marlowe (1960)" (p. 755). As previously mentioned, because of the practical difficulty with the full SDS, namely the length (33 item scale), many researchers have preferred a "shorter measure of social desirability" (Fischer 
\& Fick, 1993, p. 734). Thus, the SDS was selected for this research study.

The SDS in this study was published in one version with the ELS and accompanying state leader demographic questions and state education characteristics questions. All state superintendents in this study completed the same version of the survey including the ELS, SDS, and accompanying questions.

\section{Identification of the Population}

The population for this study included 38 out of the 52 state superintendents in the United States, District of Columbia, and the Department of Defense. The remaining 14 state superintendents' email addresses could not be retrieved and were not accessible, which resulted in the survey being sent to the remaining 38 state superintendents. Therefore, a total of 38 surveys were electronically emailed. The researcher used various processes and resources to retrieve the email addresses of the state superintendents in the United States. Such processes and resources included accessing the various state's departments of education websites, phone calls to the various state's departments of education, and utilizing the Council of Chief State School Officers website. Survey instruments were electronically emailed to the state superintendents of each state at the exact same time. As previously mentioned, a reminder email was sent to those state superintendents who did not respond after one week. An additional reminder email was sent to those superintendents who did not respond after weeks one and two. A final "Thank You" email was sent to those state superintendents who responded to the survey at the conclusion of week three. State superintendents were chosen due to their position, their role in the state, and their influence over the climate and culture of each school within their respective states.

\section{Data Collection and Analysis Procedures}

The data from the surveys was collected using Qualtrics. Qualtrics is a software that enables users to create their own web-based surveys. This survey was sent by electronic email to 38 state superintendents in the United States, including the District of Columbia and the Department of Defense. Through the use of Qualtrics, all of the data collected was graphed, sorted, and loaded into Statistical Package for Social Sciences (SPSS) as the participants in this research completed the online survey by clicking a customized link via their email.

All data was collected using an electronic survey designed in Qualtrics and analyzed through SPSS. The ELS item mean score was computed for each item on the 10-item ELS. This determined the superintendents overall mean score as well as the mean score for each item on the ELS. In order to illustrate a visual representation of the results, a table (See Table 3 and Table 4) was produced using the ELS item mean scores. In addition, a correlation matrix among variables of interest was used for the analysis of the data (See Table 7). Additionally, the SDS item mean score was computed for each item on the 10-item SDS. This determined the superintendents mean score for each item on the SDS. In order to illustrate visual representation of the results, a table (See Table 5, 6) was 
produced using the SDS item mean scores. Finally, the researchers attempted to identify and report any common themes that emerged from the qualitative portions of the survey.

\section{Findings/Results}

\section{Introduction}

The survey was mailed to 38 state superintendents in the United States. There were a total of 15 participants in this study $(N=15)$. Thus, $39.47 \%$ of the total accessible population of state superintendents in the United States, District of Columbia, and Department of Defense responded. Unfortunately, due to a limited total population of state superintendents in the United States to begin with $(N=52)$, the researchers anticipated the possibility of a small sample population, and in addition, because of their position and responsibilities as a state superintendent, the possibility of a low response rate. Thus, reminder emails were sent weekly over a three-week period in order to attempt to gain as many responses to the survey as possible. The sample size is certainly a limitation of this study. Nonetheless, the data collected as part of this study is significant and proved to be highly valuable. That is, the data collected on state superintendents in the United States for this study is not readily available or accessible. The results of this study will be reported with consideration to the relevant delimitations and limitations as previously described in the limitations section.

\section{Validity and Reliability}

The following analysis was performed with the final data. As previously reported, there were 15 responses to the survey. The no responses for each state leader demographic and state education characteristic were reported (See Table $1,2)$.

Scores produced by the ELS (10 items; $\alpha=.98$ ) and Social Desirability Scale (10 items; $\alpha=.83$ ) used in this research study were found to be highly reliable. Cronbach's Alpha is a reliability coefficient that shows the reliability of the scale. Researchers agree that Cronbach's Alpha of .8 or higher is considered acceptable (Cortina, 1993; McDonald, 1999; Revelle \& Zinbarg, 2009; Streiner, 2003).

\section{Descriptive Statistics for Variables}

The researchers developed several state superintendent leader demographic questions that were included in section one of the survey (See Appendix A). The questions in this section related to years of experience as a state superintendent, respondent's selection process (i.e., appointed or elected), prior years of experience in educational administration, gender, race, age, highest educational degree obtained, the number of ethical leadership courses completed in your educational degree program(s), the name of the educational institution where 
you completed your superintendent license program, if you completed and/or were part of any type of mentoring program/experience in your superintendent license program, if you completed an/or were part of any type of ethics training and service and/or professional development outside of the required coursework for your superintendent license program, estimate the number of ethics training and service and/or professional development hours that you completed outside of the required coursework for your superintendent license program, the professional organizations in which you have been actively involved in during the last five to ten years, and the subject area(s) and grade levels (if any) in which you are licenses to teach.

In order to clearly describe the superintendents that participated in the study, the researchers felt it was important to report the data collected from section one of the survey. Additionally, the data collected from section one of the survey is not only important to this study, but it also provides data on superintendents across the United States that otherwise is not readily available or easily accessible. Of the respondents, the majority of state superintendents in this study had zero years of experience as a state superintendent $(N=3)$. Most state superintendents in this study were appointed $(N=6)$. In regards to the prior years of experience in educational administration, most state superintendents had zero years of experience in educational administration $(N=3)$. The data also provided that majority of state superintendents in this study were female $(N=6)$. The majority of state superintendents with regards to race were White $(N=9)$. The state superintendents mostly ranged in age from ages 46-65 $(N=8)$. The doctoral degree was the highest educational degree obtained by most of the state superintendents in this study $(N=6)$. Six state superintendents reported that they completed two or less number of ethical leadership courses completed in their educational degree program. Of those superintendents included in this study, a majority of the state superintendents had no superintendent license ( $N$ $=4$ ). In regards to the respondents completing and/or being a part of any type of mentoring program/experience in their superintendent license program, most reported state superintendents reported no $(N=5)$. When asked to whether they completed and/or were part of any type of ethics training and service and /or professional development outside of the required coursework for their superintendent license program, the responses ranged between yes and no ( $N=$ 8 ) for the majority. Regarding the estimated number of ethics training and service and/or professional development hours that the respondents completed outside of the required coursework for their superintendent license program, the majority gave no response $(N=8)$. Of the professional organizations that the state superintendents belonged to, most of them belonged to other organizations than those provided in the survey $(N=5)$. Lastly, the majority of the state superintendents in this study are licensed to teach Social Studies Grades 7-12 $(N=3)$. Table 1 indicates the state leader demographic data collected from section one survey completed by the 10 respondents $(N=10)$.

The researchers also developed several state education characteristic questions that where included in section two of the survey. These questions focused on the total student enrollment size of each respondent's state, total number of 
superintendents in their state, total annual budget for education in their state, the majority of school district locale (i.e., Urban, Suburban, Rural) in their state, and the overall state rank (i.e., grade, score, and rank).

In order to clearly describe the state education characteristics in which the respondents worked, the researchers felt it was important to report the data collected from section two of the survey. The data collected from section two of the survey is not only important to this study, but it also provides data on state education across the United States that otherwise is not readily available or easily accessible. Of the respondents in this survey, the majority of the state superintendents' total enrollment size were 117,000 students $(N=2)$. Most of the respondents in this survey had 178 total number of superintendents in their state $(N=3)$. Many of the state superintendents' annual budget was 1.38 billion ( $N$ $=2)$. For most of the state superintendents, the majority of their school district locale was rural $(N=9)$. In regards to the overall state rank for the respondents' states, their grades ranged between a $\mathrm{C}+(N=3)$ and $\mathrm{C}-(N=3)$, and their scores were $7.1(N=2)$, and the rank was $15(N=2)$.

Table 1. Demographics of Respondents $(\mathrm{N}=10)$

\begin{tabular}{|c|c|c|}
\hline State Leader Demographics & Value Label & $\mathbf{N}$ \\
\hline \multirow{8}{*}{$\begin{array}{l}\text { Years of Experience as a State } \\
\text { Superintendent }\end{array}$} & 0 & 3 \\
\hline & 1 & 2 \\
\hline & 1.5 & 1 \\
\hline & 2 & 1 \\
\hline & 4 & 1 \\
\hline & 5.5 & 1 \\
\hline & 6 & 1 \\
\hline & No Response & 0 \\
\hline \multirow[t]{3}{*}{ Respondent's Selection Process } & Appointed & 6 \\
\hline & Elected & 3 \\
\hline & No Response & 1 \\
\hline \multirow{6}{*}{$\begin{array}{l}\text { Prior Years of Experience in } \\
\text { Educational Administration }\end{array}$} & 0 & 3 \\
\hline & 4 & 2 \\
\hline & 17 & 1 \\
\hline & 18 & 2 \\
\hline & 35 & 2 \\
\hline & No Response & 0 \\
\hline \multirow[t]{3}{*}{ Gender } & Female & 6 \\
\hline & Male & 4 \\
\hline & No Response & 0 \\
\hline \multirow[t]{7}{*}{ Race } & White & 9 \\
\hline & Black or African American & 1 \\
\hline & $\begin{array}{c}\text { American Indian or Alaska } \\
\text { Native }\end{array}$ & 0 \\
\hline & Asian & 0 \\
\hline & $\begin{array}{l}\text { Native Hawaiian or Pacific } \\
\text { Islander }\end{array}$ & 0 \\
\hline & Other & 0 \\
\hline & No Responses & 0 \\
\hline \multirow[t]{5}{*}{ Age } & $<35$ & 0 \\
\hline & $36-45$ & 1 \\
\hline & 46-55 & 4 \\
\hline & $55-65$ & 4 \\
\hline & $>65$ & 1 \\
\hline
\end{tabular}




\begin{tabular}{|c|c|c|}
\hline & No Response & 0 \\
\hline \multirow{5}{*}{$\begin{array}{l}\text { Highest Educational Degree } \\
\text { Obtained }\end{array}$} & Doctoral Degree & 6 \\
\hline & Master's Degree & 4 \\
\hline & Bachelor's Degree & 0 \\
\hline & Other & 0 \\
\hline & No Response & 0 \\
\hline \multirow{7}{*}{$\begin{array}{l}\text { The number of ethical leadership } \\
\text { courses completed in your } \\
\text { educational degree program(s) }\end{array}$} & 0 & 0 \\
\hline & 1 & 4 \\
\hline & 2 & 2 \\
\hline & 3 & 1 \\
\hline & 4 & 1 \\
\hline & 5 or more & 1 \\
\hline & No Response & 1 \\
\hline \multirow{6}{*}{$\begin{array}{l}\text { The name of the educational } \\
\text { institution where you completed } \\
\text { your superintendent license } \\
\text { program }\end{array}$} & No Superintendent License & 4 \\
\hline & Kansas State University & 1 \\
\hline & Nova Southeastern University & 1 \\
\hline & University of St. Thomas & 1 \\
\hline & State of Michigan & 1 \\
\hline & No Response & 2 \\
\hline \multirow{4}{*}{$\begin{array}{l}\text { If you completed and/or were part } \\
\text { of any type of mentoring } \\
\text { program/experience in your } \\
\text { superintendent license program }\end{array}$} & Yes & 3 \\
\hline & No & 5 \\
\hline & No Response & 2 \\
\hline & & \\
\hline \multirow{4}{*}{$\begin{array}{l}\text { If you completed and/or were part } \\
\text { of any type of ethics training and } \\
\text { service and/or professional } \\
\text { development outside of the } \\
\text { required coursework for your } \\
\text { superintendent license program }\end{array}$} & Yes & 4 \\
\hline & No & 4 \\
\hline & No Response & 2 \\
\hline & & \\
\hline \multirow{4}{*}{$\begin{array}{l}\text { Please estimate the number of } \\
\text { ethics training and service and/or } \\
\text { professional development hours } \\
\text { that you completed outside of the } \\
\text { required coursework for your } \\
\text { superintendent license program }\end{array}$} & 5 & 1 \\
\hline & 20 & 1 \\
\hline & No Response & 8 \\
\hline & & \\
\hline \multirow{8}{*}{$\begin{array}{l}\text { The professional organizations in } \\
\text { which you have been actively } \\
\text { involved in during the last five to } \\
\text { ten years }\end{array}$} & $\begin{array}{c}\text { American Association of School } \\
\text { Administrators (AASA) }\end{array}$ & 4 \\
\hline & $\begin{array}{l}\text { National School Boards } \\
\text { Association (NSBA) }\end{array}$ & 3 \\
\hline & $\begin{array}{l}\text { The Association of Supervision } \\
\text { and Curriculum Development } \\
\text { (ASCD) }\end{array}$ & 4 \\
\hline & $\begin{array}{c}\text { National Association of State } \\
\text { Boards of Education (NASBE) }\end{array}$ & 2 \\
\hline & $\begin{array}{c}\text { Urban Superintendents } \\
\text { Association of America (USAA) }\end{array}$ & 0 \\
\hline & $\begin{array}{l}\text { National Association of State } \\
\text { Administrators and Supervisors } \\
\text { of Private Schools (NASASPS) }\end{array}$ & 5 \\
\hline & Other & 1 \\
\hline & No Response & \\
\hline \multirow{6}{*}{$\begin{array}{l}\text { The subject area(s) and grade } \\
\text { levels (if any) in which you are } \\
\text { licenses to teach }\end{array}$} & No Teaching License & 2 \\
\hline & Biological Science Grades 6-12 & 1 \\
\hline & $\begin{array}{l}\text { Elementary Education Grades 1- } \\
8\end{array}$ & 1 \\
\hline & Elementary and K12 Technology & 1 \\
\hline & Social Studies Grades 7-12 & 3 \\
\hline & No Response & 2 \\
\hline
\end{tabular}


Table 2. State Education Characteristics of Respondents' Respective State $(\mathrm{N}=10)$

\begin{tabular}{|c|c|c|}
\hline State Education Characteristics & Value Label & $\mathbf{N}$ \\
\hline \multirow{9}{*}{$\begin{array}{l}\text { Total State Enrollment Size (in } \\
\text { thousands) }\end{array}$} & 90 & 1 \\
\hline & 117 & 2 \\
\hline & 124 & 1 \\
\hline & 189 & 1 \\
\hline & 277 & 1 \\
\hline & 500 & 1 \\
\hline & 750 & 1 \\
\hline & 900 & 1 \\
\hline & No Response & 1 \\
\hline \multirow{7}{*}{$\begin{array}{l}\text { Total Number of Superintendents } \\
\text { in State }\end{array}$} & 55 & 1 \\
\hline & 152 & 1 \\
\hline & 155 & 1 \\
\hline & 178 & 3 \\
\hline & 280 & 1 \\
\hline & 435 & 1 \\
\hline & No Response & 2 \\
\hline \multirow{8}{*}{$\begin{array}{l}\text { Total Annual Budget for } \\
\text { Education in State }\end{array}$} & 1.5 million & 1 \\
\hline & 768 million & 1 \\
\hline & 1 billion & 1 \\
\hline & 1.38 billion & 2 \\
\hline & 2.4 billion & 1 \\
\hline & 6 billion & 1 \\
\hline & 10 billion & 1 \\
\hline & No Response & 2 \\
\hline \multirow{3}{*}{$\begin{array}{l}\text { Majority of School District } \\
\text { Locale }\end{array}$} & Urban & 0 \\
\hline & Suburban & 1 \\
\hline & Rural & 9 \\
\hline \multirow{10}{*}{ Overall State Rank (Grade) } & $\mathrm{B}+$ & 0 \\
\hline & $\mathrm{B}$ & 0 \\
\hline & B- & 1 \\
\hline & $\mathrm{C}+$ & 3 \\
\hline & $\mathrm{C}$ & 2 \\
\hline & $\mathrm{C}-$ & 3 \\
\hline & $\mathrm{D}+$ & 0 \\
\hline & $\mathrm{D}$ & 0 \\
\hline & D- & 0 \\
\hline & No Response & 1 \\
\hline \multirow{8}{*}{ Overall State Rank (Score) } & 70.3 & 1 \\
\hline & 71.7 & 1 \\
\hline & 71.8 & 1 \\
\hline & 73.8 & 1 \\
\hline & 77.1 & 2 \\
\hline & 78.5 & 1 \\
\hline & 79.3 & 1 \\
\hline & No Response & 2 \\
\hline \multirow{8}{*}{ Overall State Rank (Rank) } & 10 & 1 \\
\hline & 14 & 1 \\
\hline & 15 & 2 \\
\hline & 26 & 1 \\
\hline & 34 & 1 \\
\hline & 35 & 1 \\
\hline & 38 & 1 \\
\hline & No Response & 2 \\
\hline
\end{tabular}


As previously mentioned, this study focused on the ethical leadership perspectives of state superintendents in the United States, District of Columbia, and Department of Defense. Secondly, this study examined to what extent the ethical leadership perspectives of the state superintendents in the United States were correlated with state education characteristics. Additionally, this study examined to what extent the ethical leadership perspectives of state superintendents in the United States were correlated with state leader demographics. The research questions guiding this study are presented below.

\section{Research Question One}

The first research question guiding this study was: What are the ethical leadership perspectives of the state superintendents in the United States?

This research question was tested by administering the ELS to all state superintendents in the study. The researchers computed the ELS mean score for each state superintendent in the study (See Table 3). Additionally, the researchers computed the item mean score for each statement on the ELS (See Table 4). The ELS mean scores varied $(M=2.10-M=5.00)$. The ELS mean score for all responses $(N=9)$ was $(M=3.8)$. The results of the ELS indicate that state superintendents in the United States have slightly positive ethical leadership perspectives (See Table $3 \&$ Table 4) with a lower overall mean $(M=3.8)$ compared to similar studies utilizing the ELS.

Table 3. Ethical Leadership Mean Scores $(\mathrm{N}=9)$

\begin{tabular}{|l|c|c|}
\hline ELS Mean Scores & $\mathbf{M}$ & $\mathbf{N}$ \\
\cline { 2 - 3 } & 2.10 & 1 \\
\cline { 2 - 3 } & 4.30 & 1 \\
\cline { 2 - 3 } & 4.50 & 1 \\
\cline { 2 - 3 } & 4.70 & 2 \\
\cline { 2 - 3 } & 4.80 & 1 \\
\cline { 2 - 3 } & 4.90 & 1 \\
\cline { 2 - 3 } & 5.00 & 1 \\
\hline
\end{tabular}

The SDS was included in this study to control for any possible response bias on the ELS. The researcher computed the SDS mean score for each state superintendent in the study (See Table 5). Additionally, the researchers computed the item mean score for each statement on the SDS (See Table 6). The SDS mean scores varied from $(M=5.00-M=9.00)$. The ELS mean score for all responses $(N=9)$ was $(M=7)$. The results of the SDS indicate that state superintendents in the United States were answering the questions in a slightly socially desirable fashion (See Table $3 \&$ Table 4 ). That is, state superintendents in the United States have somewhat highly socially desirable response tendencies. 
Table 4. Ethical Leadership Item Mean Scores $(\mathrm{N}=9)$

\begin{tabular}{|l|c|c|c|}
\hline ELS Statement & SD & M & N \\
\hline $\begin{array}{l}\text { S1. Listens to what } \\
\text { employees have to } \\
\text { say }\end{array}$ & 0.96 & 4.44 & 9 \\
\hline $\begin{array}{l}\text { S2. Disciplines } \\
\text { employees who } \\
\text { violate ethical } \\
\text { standards }\end{array}$ & 0.96 & 4.44 & 9 \\
\hline $\begin{array}{l}\text { S3. Conducts his/her } \\
\text { personal life in an } \\
\text { ethical manner }\end{array}$ & 0.68 & 4.44 & 9 \\
\hline $\begin{array}{l}\text { S4. Has the best } \\
\text { interests of employees } \\
\text { in mind }\end{array}$ & 0.96 & 4.44 & 9 \\
\hline $\begin{array}{l}\text { S5. Makes fair and } \\
\text { balanced decisions }\end{array}$ & 0.96 & 4.44 & 9 \\
\hline S6. Can be trusted & 0.96 & 4.56 & 9 \\
\hline $\begin{array}{l}\text { S7. Discusses ethics } \\
\text { or values with } \\
\text { employees }\end{array}$ & 0.94 & 4.00 & 9 \\
\hline $\begin{array}{l}\text { S8. Sets an example } \\
\text { of how to do things } \\
\text { the right way in terms } \\
\text { of ethics }\end{array}$ & 0.96 & 4.56 & 9 \\
\hline $\begin{array}{l}\text { S9. Defines success } \\
\text { not just by results, but } \\
\text { also the way } \\
\text { they are obtained }\end{array}$ & 0.96 & 4.67 & 9 \\
\hline $\begin{array}{l}\text { S10. When making } \\
\text { decisions, asks "What } \\
\text { is the right } \\
\text { thing to do? }\end{array}$ & 0.94 & & 9 \\
\hline
\end{tabular}

Table 5. Social Desirability Mean Scores ( $\mathrm{N}=9)$

\begin{tabular}{|l|c|c|}
\hline SDS Mean Scores & M & N \\
\hline \multirow{3}{*}{$\begin{array}{l}\text { Social Desirability Mean } \\
\text { Scores }\end{array}$} & 5.00 & 1 \\
\cline { 2 - 3 } & 7.00 & 4 \\
\cline { 2 - 3 } & 9.00 & 1 \\
\cline { 2 - 3 } & No Response & 3 \\
\hline
\end{tabular}


Table 6. Social Desirability Item Mean Scores $(\mathrm{N}=9)$

\begin{tabular}{|l|c|c|c|}
\hline SDS Statement & \multicolumn{1}{|c|}{ SD } & M & N \\
\hline $\begin{array}{l}\text { S1. I like to gossip } \\
\text { at times }\end{array}$ & 0.45 & 1.71 & 9 \\
\hline $\begin{array}{l}\text { S2. There have been } \\
\text { occasions when I } \\
\text { took advantage of } \\
\text { someone }\end{array}$ & 0.35 & 1.86 & 9 \\
\hline $\begin{array}{l}\text { S3. I'm always } \\
\text { willing to admit it } \\
\text { when I make a } \\
\text { mistake }\end{array}$ & 0.35 & 1.14 & 9 \\
\hline $\begin{array}{l}\text { S4. I always try to } \\
\text { practice what I } \\
\text { preach }\end{array}$ & 0.00 & 1.00 & 9 \\
\hline $\begin{array}{l}\text { S5. I sometimes try } \\
\text { to get even rather } \\
\text { than forgive and } \\
\text { forget }\end{array}$ & 0.00 & 2.00 & 9 \\
\hline $\begin{array}{l}\text { S6. At times I have } \\
\text { really insisted on } \\
\text { having things my } \\
\text { own way }\end{array}$ & 0.49 & 1.43 & 9 \\
\hline $\begin{array}{l}\text { S7. There have been } \\
\text { occasions when I } \\
\text { felt like smashing } \\
\text { things }\end{array}$ & 0.45 & 1.71 & 9 \\
\hline $\begin{array}{l}\text { S8. I never resent } \\
\text { being asked to } \\
\text { return a favor }\end{array}$ & 0.49 & & \\
\hline $\begin{array}{l}\text { S9. I have never } \\
\text { been irked when } \\
\text { people express ideas } \\
\text { very different from } \\
\text { my own }\end{array}$ & 0.45 & & 9 \\
\hline $\begin{array}{l}\text { S10. I have never } \\
\text { deliberately said } \\
\text { something that hurt } \\
\text { someone's feelings }\end{array}$ & & & \\
\hline
\end{tabular}

\section{Research Question Two and Three}

The second research question guiding this study was: To what extent are the ethical leadership perspectives of state superintendents in the United States correlated with state leader demographics?

The third research question guiding this study was: To what extent are the ethical leadership perspectives of state superintendents in the United States correlated with state education characteristics?

Due to the low response rate $(N=15)$, incomplete surveys, and a relatively 
small accessible population to begin with $(N=38)$, the researchers decided to only analyze five variables. These five variables were selected based on the results of previous and similar studies (D. Fowler, 2014; D. Fowler \& Johnson, 2014). In previous research, age, gender, student achievement, and highest educational degree proved to be statistically significant and vary according to the ethical leadership perspectives of superintendents. Thus, the researchers decided to use these four variables with the addition of the SDS scores. The SDS mean scores were included in this study to control for possible response bias on the ELS. The researchers reported only the correlation matrix among these five variables with the ELS (See Table 7). Furthermore, the researchers conducted a correlation analysis with the previously mentioned variables of interest including the ELS mean scores, SDS mean scores, gender, age, highest educational degree (Doctoral degree versus Master's degree), and student achievement (state national ranking). As shown in Table 7, the magnitude of correlation coefficients ranged from -.57 to .88 . The only statistically significant correlation coefficient was between the ELS mean scores and SDS mean scores $(.88)$.

Table 7.Correlation Coefficients between Variables

\begin{tabular}{|l|c|c|c|c|c|c|}
\hline & $\mathbf{1}$ & $\mathbf{2}$ & $\mathbf{3}$ & $\mathbf{4}$ & $\mathbf{5}$ & $\mathbf{6}$ \\
\hline 1. ELS Score & - & & & & & \\
\hline 2. SDS Score & $.88^{*}$ & - & & & & \\
\hline 3. Gender & -.50 & .00 & - & & & \\
\hline $\begin{array}{l}\text { 4. Highest } \\
\text { Educational } \\
\text { Degree }\end{array}$ & -.20 & .61 & .07 & - & & \\
\hline 5. Age & -.57 & .00 & .45 & .15 & - & \\
\hline $\begin{array}{l}\text { 6. Student } \\
\text { Achievement }\end{array}$ & .35 & -.15 & .19 & -.13 & .00 & - \\
\hline
\end{tabular}

Note: $* \mathrm{p}<.05$.

\section{Qualitative Questions within Survey}

The surveys used in this study included four qualitative questions. The researchers attempted to identify common themes that emerged with regard to the responses to these questions. If the respondents selected "yes" to open-ended questions one and three (See Table 8, 10), a text box would appear asking them to "please explain and/or provide examples". If they answered "no", then the respondent would automatically move onto the next question in the survey. In addition to these two types of questions, two other open-ended questions were included in the survey that all state superintendents had the opportunity to answer (See Table 9, 11). The qualitative questions and responses are reported below (See Tables 8, 9, 10, 11). For questions one and three, the additional questions and answers are reported in their entirety below Table 8 and Table 10. For questions two and four, the question and answers are reported below Table 9 and Table 11. Additionally, in order to provide an interesting analysis, the researchers created word clouds for the responses to questions two and four in order to provide a 
visual for common themes (in this case, words) that emerged (See Figure 1, 2).

Table 8. Survey Open-Ended Question One $(\mathrm{N}=9)$

\begin{tabular}{|l|c|c|}
\hline Survey Question & Value Label & N \\
\hline $\begin{array}{l}\text { Do you believe that your } \\
\text { ethical leadership } \\
\text { perspectives are affected by } \\
\text { your state education } \\
\text { characteristics (i.e., total } \\
\text { students in your state, } \\
\text { majority district locale in } \\
\text { your state, state academic } \\
\text { achievement, state } \\
\text { education budget, etc.)? }\end{array}$ & Yes & 3 \\
\cline { 2 - 3 } & No & 6 \\
\hline
\end{tabular}

Although three state superintendents selected "yes" to survey open-ended question one, only one chose to respond to the additional question that appeared (by selecting yes). This additional question was: Please explain and/or provide examples of why you believe that your ethical leadership perspectives are affected by your state education characteristics (i.e., total students in your state, majority district locale in your state, state academic achievement, state education budget, etc.).

One state superintendent responded "Moral and ethical leadership are critical to establishing trust and credibility." Due to only one response to this question, the researchers were unable to identify any common emerging themes.

Table 9. Survey Open-Ended Question Two $(\mathrm{N}=9)$

\begin{tabular}{|l|c|c|}
\hline Survey Question & Value Label & N \\
\hline $\begin{array}{l}\text { What do believe to be the } \\
\text { most pressing issues facing } \\
\text { state superintendents? }\end{array}$ & Response & 9 \\
\cline { 2 - 3 } & No Response & 0 \\
\hline
\end{tabular}

State superintendents had a variety of responses to this question in the survey. However, some common themes did emerge. As shown in Figure 1, the common themes that emerged included funding, accountability, and student achievement. Other responses included items such as mental health, work-life balance, navigating political demands and mandates, and in general an attack on public education. 
Figure 1. Word Cloud from Question Two $(\mathrm{N}=9)$

\section{accountability achievement}

attacking balancing branch budgets demands disparities driving education essa executive funding

expectations federal TU health improvement legislature meeting

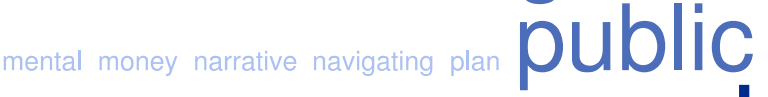
state student

Table 10. Survey Open-Ended Question Three $(\mathrm{N}=9)$

\begin{tabular}{|l|c|c|}
\hline Survey Question & Value Label & N \\
\hline $\begin{array}{l}\text { Do you believe that your ethical leadership perspectives are } \\
\text { affected by your own leader demographics (i.e., age, } \\
\text { years of experience, gender, race, etc.)? }\end{array}$ & Yes & 6 \\
\cline { 2 - 3 } & No & 3 \\
\hline
\end{tabular}

Although six state superintendents selected "yes" to survey open-ended question one, only two chose to respond to the additional question that appeared (by selecting yes). This additional question was: Please explain and/or provide examples of why you believe your ethical leadership perspectives are affected by your own leader demographics (i.e., age, years of experience, gender, race, etc.).

One state superintendent responded "I am a moral leader who believes that ethical conduct builds trust as we carry out the business of educating young people." Another superintendent responded "With experience comes wisdom, with mistakes comes new learning and being a person of color lends me a unique view of the world, especially since I am bi-racial." Due to only two responses to this question, the researchers were unable to identify any common emerging themes.

Table 11. Survey Open-Ended Question Four $(\mathrm{N}=9)$

\begin{tabular}{|l|c|c|}
\hline Survey Question & Value Label & N \\
\hline $\begin{array}{l}\text { What do you believe most } \\
\text { affects your ethical }\end{array}$ & Response & 6 \\
\cline { 2 - 3 } $\begin{array}{l}\text { leadership perspectives in } \\
\text { decision-making? }\end{array}$ & No Response & 3 \\
\hline
\end{tabular}

State superintendents had a variety of responses to this question in the survey. However, some common themes did emerge. As shown in Figure 2, the common themes that emerged included culture, ethics, and family. Two superintendents 
responded "doing the right thing." Other responses included items such spiritual beliefs, character, years of experience, and relationships with others.

Figure 2. Word Cloud from Question Four $(\mathrm{N}=6)$

\section{culture

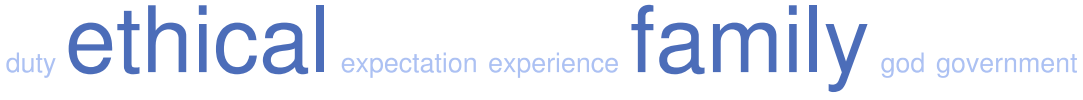 \\ governor leadership learned making modeled north others path promotes proper provides state}

\section{Summary}

This section reported all of the data collected from the surveys including the descriptive statistics for all variables, the results of the ELS, the results of the SDS, and the results from the correlation analysis, and the responses to the qualitative questions in the survey.

\section{Discussion/Conclusions}

\section{Introduction}

The purpose of this final section is to provide a summary of the results, the implications, and the researchers' recommendations for future research. Furthermore, the researchers provide this information as it relates to state superintendents in the United States, District of Columbia, and Department of Defense. Additionally, the researchers report this information as it relates to their state leader demographics, state education characteristics, and ethical leadership perspectives. The results of study, implications, and recommendations for future research are reported in light of the previously reported delimitations and limitations to the study.

\section{Summary of Results}

The first research question guiding this study was: What are the ethical leadership perspectives of the state superintendents in the United States? The results of the ELS indicated that state superintendents in the study had slightly positive ethical leadership perspectives. The ELS mean score was $(M=3.8)$. On a five-point Likert scale response format as used in this study in accordance with the ELS, three is the mid-point. Based on the creators of the ELS (Brown, Harrison, \& Trevino, 2005), scores below three are considered to represent 
negative ethical leadership perspectives. Thus, the researchers determined that the state superintendents in this study had slightly positive ethical leadership perspectives. However, in comparison to previous studies utilizing the ELS, the overall mean $(M=3.8)$ would be considered low in comparison.

The SDS was included in this study to help control for any socially desirable response tendencies that might explain the results of the ELS. The SDS mean score was $(M=7)$. This would suggest the possibility that state superintendents in this study were answering the questions in a slightly socially desirable fashion. In addition, the results of the correlation coefficient proved that the only statistically significant correlation coefficient was between the ELS mean scores and SDS mean scores (.88).

The second research question guiding this study was: To what extent are the ethical leadership perspectives of state superintendents in the United States correlated with state leader demographics? The qualitative results of this study indicate that state superintendents believe items such as race, morals, ethical conduct, experience, and age all affect their ethical leadership perspectives. Due to the limited number of responses to the survey, the researchers were unable to determine if any of the state leader demographics were statistically correlated with the ethical leadership perspectives of state superintendents.

The third research question guiding this study was: To what extent are the ethical leadership perspectives of state superintendents in the United States correlated with state education characteristics?The qualitative results of this study indicate that state superintendents believe items such as leading morally and ethically are key to building trust and credibility. Due to the limited number of responses to the survey, the researchers were unable to determine if any of the state education characteristics were statistically correlated with the ethical leadership perspectives of state superintendents.

\section{Implications}

Before reporting theimplications of this study, it is important to note that the total population $(N=52)$ was a relatively low population to begin with. That is, there are only 52 state superintendents in the United States, District of Columbia, and Department of Defense. As previously reported, after much research including phone calls, emails, and Internet searches, the accessible population for this study $(N=38)$ was 14 less than the total population of which 15 responded. The researchers report these implications with respect to the small sample size.

The results of this study indicated that the ethical leadership perspectives of state superintendents in the United States are slightly positive with a mean of $(M=3.8)$. This implies that state superintendents have somewhat positive ethical leadership perspectives. However, it is worth noting that some variation in the ELS mean scores did exist. The ELS mean scores ranged from $(M=2.10$ $-M=5.0$ ) suggesting that state superintendents have differences in their ethical leadership perspectives. The results of this study indicated that the majority of state superintendents $(N=4)$ completed only one ethical leadership 
course in their educational degree programs. In addition, the results of this study indicated that the majority of state superintendents $(N=5)$ did not complete or were part of any type of mentoring program/experience in their superintendent license program. Finally, the results of this study indicated that not all state superintendents carry a valid superintendent license. In fact, the results indicated that the majority of state superintendents in this study $(N=4)$ did not have a superintendent license. These results may be due to the fact that almost half of the state superintendents $(N=4)$ had only obtained a Master's degree. The researchers believe this implicates the need for certain requirements with regard to highest educational degree obtained and licensure(s) held in order to serve as a state superintendent in the United States.

The results of this study indicated that the social desirability of state superintendents in this study were slightly high. That is, the mean score on the SDS $(M=7)$ indicates that the superintendents in the study were answering the questions in a slightly socially desirable fashion. These results may imply that the state superintendents are certainly aware of the political nature of their position not only their daily operations, but also when answering surveys such as the one utilized in this study, more specifically, as it applies to the results of the SDS and ELS.

Again, due to the limited number of responses in this study, the researchers were prevented from developing any practical suggestions relating to the state leader demographics and state education characteristics. However, the researchers strongly contend that the data collected on state superintendents in the United States, District of Columbia, and Department of Defense that is not readily available or accessible (See Table 1,2). Thus, the study and information collected proved to be highly valuable with regards to this particular perspective. Additionally, the researchers collected qualitative data from the open-ended questions in the survey and this data was previously reported. However, again, due to the limited number of responses to the qualitative questions in this study, the researchers were prevented from developing any practical suggestions relating to the state leader demographics and state education characteristics.

\section{Recommendations for Future Research}

This study had a low response rate $(N=15)$, due to this limitation to this study, the researchers suggest that a similar study may benefit from face-toface meetings versus electronically mailed surveys. Some researchers suggest that there are potential disadvantages to online surveys (Andres, 2012; Fowler \& Johnson, 2014). Thus, the researchers believe that face-to-face meetings possibly will yield more valuable data to be analyzed.

Due to the unique nature of this research project (i.e., Ronald E. McNair ${ }^{1}$ Scholar Research Project) and time restrictions involved, the researchers only

\footnotetext{
${ }^{1}$ The Ronald E. McNair Scholar Program is a division of the Office of Federal TRIO Programs in the United States. The program is highly selective and provides low income and first generation college students from underrepresented groups an opportunity to engage in scholastic undertakings that increase the likelihood for matriculation into a doctoral program.
} 
had three weeks to send surveys and collect data. The researchers suggest that future studies allow for a longer duration of data collection. State superintendents are often busy and receive numerous emails on a daily basis. The researchers believe it would be beneficial to future studies with state superintendents to allow for a longer time frame to complete the surveys.

This study found that the ELS and SDS were correlated. Furthermore, based on the results of this study and others (Brown, Harrison, \& Trevino, 2005; Fowler, 2014a; Fowler \& Johnson, 2014) using the ELS, the majority of the scores tend to be over 4.0. Although the ELS proved to be a reliable instrument in this study, the researchers suggest future studies focused on validating another research instrument that might provide more variation in the ethical leadership perspective scores of individuals, namely school leaders. In the meantime, future studies could utilize someone other than the state superintendents (i.e., assistant state superintendent, state school board members, etc.) to complete the ELS based on their perceptions of the state superintendent's ethical leadership perspectives. Consequently, allowing for the possibility to compare how state superintendents rate their own ethical leadership perspectives versus how others rate them. Thus, possibly yielding more data and variance as it relates to the ELS and the ethical leadership perspectives of state superintendents in the United States and elsewhere.

The SDS mean scores were found to be a statistically significant correlation with the ELS mean scores (.88). This result is in contrast to previous studies (Fowler, 2014a; Fowler \& Johnson, 2014) using the ELS and the SDS, which found that the SDS and ELS were not correlated. This implies that more studies using the ELS and SDS could prove beneficial in determining whether or not the two scales are correlated or not.

In contrast to the extant literature (Fowler, 2014a; Fowler \& Johnson, 2014), age, gender, student achievement, and highest educational degree were not statistically correlated with the ethical leadership perspectives of the superintendents in this study. Future research will need to be conducted in order to determine if state superintendents and district superintendents' ethical leadership perspectives do indeed vary according to these variables, as well as others.

Finally, the researchers suggest that this study be replicated with the following possible additions to the study: 1. conduct interviews face-to-face with each state superintendent in order to ensure ample data collection; 2 . conduct the study over a longer time period in order to allow state superintendents more time to complete surveys; 3 . launch study only when the research team can confirm the accurate email addresses of all 52 state superintendents in order to ensure increase of total accessible population; and 4. possibly include some sort of incentive for state superintendents who complete the survey. Because of the already low total population $(N=52)$, the researchers believe the key to replicating this study will lie in obtaining the maximum amount of completed surveys possible. 


\section{References}

Andres, L. (2012). Designing and doing survey research. London: Sage.

Barton, L. T. (2013). Knowledge of effective educational leadership practices. NCPEA International Journal of Educational Leadership Preparation, 8(1), 93-102.

Bon, S. C. (2012). Examining the crossroads of law, ethics, and education leadership. Journal of School Leadership, 22, 285-308.

Bowers, T. (2009). Connections between ethical leadership behavior and collective efficacy levels as perceived by teachers (Doctoral dissertation). Retrieved from ProQuest Dissertation and Theses database.

Brown, M., Trevino, L., \& Hartman, L. (2003). A qualitative investigation of perceived executive ethical leadership: Perceptions from inside and outside the executive suite. Thousand Oaks, CA: Sage Publication, Inc.

Brown, M., Harrison, D., \& Trevino, L. (2005). Ethical leadership: A social learning perspective for construct development and testing. Organizational Behavior and Human Decision Processes, 97, 117-134.

Brown, M. \& Trevino, L. (2006). Ethical leadership: A review and future directions. The Leadership Quarterly, 17, 595-616.

Cortina, J.M. (1993). What is coefficient alpha? An examination of theory and applications. Journal of Applied Psychology, 78, 98-104.

Education Week/Editorial Projects for Education. (2016). Education rankings put states, Nation to the Test. Retrieved from http://bit.ly/2umzlBb.

Ehrich, L. C., Harris, J., Klenowski, V., Smeed, J., \& Spina, N. (2015). The centrality of ethical leadership. Journal of Educational Leadership, 53(2), 197-214.

Fischer, D.G. \& Fick, C. (1993). Measuring social desirability: Short forms of the marlowe-crowne social desirability scale. Educational and Psychological Measurement, 53, 417-424

Fowler, D. (2014a). An investigation of ethical leadership perspectives among Ohio school district superintendents. Retrieved from http://bit.ly/2s4HlpG.

Fowler, F. (2014b). Survey research methods. Beverly Hills, CA: Sage Publications, Inc.

Fowler, D., \& Johnson, J. (2014). An investigation of ethical leadership perspectives among Ohio school district superintendents. Education Leadership Review of Doctoral Research, 1(2), 96-112.

Gamson, D. A. (2004). The infusion of corporate values into progressive education. Journal of Educational Administration, 42(2), 137-159.

Jacobs, K., \& Kritsonis, W. (2007). An analysis of the objective ethics in educational leadership through Ayn Rand's The Virtue of Selfishness (1964). The Lamar University Electronic Journal of Student Research, 1-6.

Macintyre, A. (1998). A short history of ethics: A history of moral philosophy from the Homeric age to the twentieth century. London: Rutledge

McDonald, R. P. (1999). Test theory: A unified treatment. Psychology Press.

MDE. (2016). Retrieved from http://bit.ly/2sUmuIo.

Noppe, R., Sheng, B., Webb, C., \& Yager, S. (2013). Decision-making and problempractices of superintendents confronted by district dilemmas. NCPEA International Journal of Educational Leadership Preparation, 8(1), 103-120.

NPBEA. (2015). Professional Standards for Educational Leaders (PSEL). Retrieved from http://bit.ly/2tslEnM.

Revelle, W. \& Zinbarg, R. (2009). Coefficients alpha, beta, omega, and the glb: Comments on sijtsma. Psychometrika, 74(1), 145-154.

Russo, A. (2013). Superintendents: States Switch Between Elected \& Appointed. Retrieved from http://bit.ly/2s4PoTd. 
Sax, G. (1979). Foundations of educational research. Englewood Cliffs, NJ: PrenticeHall, Inc.

Schachter, R. (2011). Taking the helm in cheating scandals. District Administration, 5054.

Streiner, D.L. (2003). Starting at the beginning: an introduction to coefficient alpha andinternal consistency. Journal of Personality Assessment, 80, 99-103.

Strahan, R. \& Gerbasi, K.C. (1972). Short, homogenous versions of the marlowecrowne social desirability scale. Journal of Clinical Psychology, 28, 191-193.

Starratt, R. (1991). Building an ethical school: a theory for practice in educational leadership. $E A Q, 27(2), 105-202$. 


\section{Appendices}

\section{Appendix A: The Survey}

\section{Ethical Leadership Perspectives Survey}

Thank you for your willingness to consider completing the following survey.

The survey is designed for individuals serving as a State Superintendent and/or Commissioner of Education in the United States. It seeks your input regarding your state education characteristics (i.e., enrollment size, budget range, student achievement of your state), your own leader demographics (i.e., age, gender, years of experience, highest degree obtained, coursework, membership in professional organizations), and your leadership perspectives.

The survey should take you no more than 8 to 10 minutes to complete. No risks or discomforts are anticipated if you complete the survey. You will not personally benefit by participating in this study. There may however be a societal benefit from better understanding the leadership perspectives of state superintendents as they relate to state education characteristics and leader demographics.

Your participation is voluntary, anonymous, and responses about your state will be confidential. At no time will your individual responses be made available to anyone outside of the research team. State-level data associated with your responses will not be reported in any public forum. That is, responses that may in some way reflect your specific state will not be shared in public reports.

This study has been reviewed by The University of Mississippi's Institutional Review Board (IRB). If you have any questions, concerns, or reports regarding your rights as a participant of research, please contact the IRB at (662) 915-7482.

\section{The survey is broken up into five short sections:}

Section 1, titled 'State Leader Demographics', asks questions regarding your own leader demographics such as your age, gender, years of experience, highest degree obtained, coursework, and membership in professional organizations.

Section 2, titled 'State Education Characteristics' asks questions regarding your state education characteristics such as enrollment size, budget range, and student achievement in your state.

$\underline{\text { Section } 3}$, titled 'Leadership Perspectives' asks questions regarding your leadership perspectives.

Section 4, titled 'Extended Response Questions', asks for your thoughts regarding the affect state education characteristics/state leader demographics have on ethical leadership perspectives. This section also includes questions regarding your own belief as to what are the most pressing issues facing state superintendents/commissioners of education, and what you believe to most affect your ethical leadership perspectives in decision-making.

Lastly, Section 5, titled 'Personal Attitudes and Traits', asks for your thoughts regarding your personal attitudes and traits.

\section{Section 1: State Leader Demographics}

Please indicate

The number of years' experience you have as a state superintendent/commissioner of education

If you are an elected state superintendent/commissioner of education or appointed state superintendent/commissioner of education?

Elected 


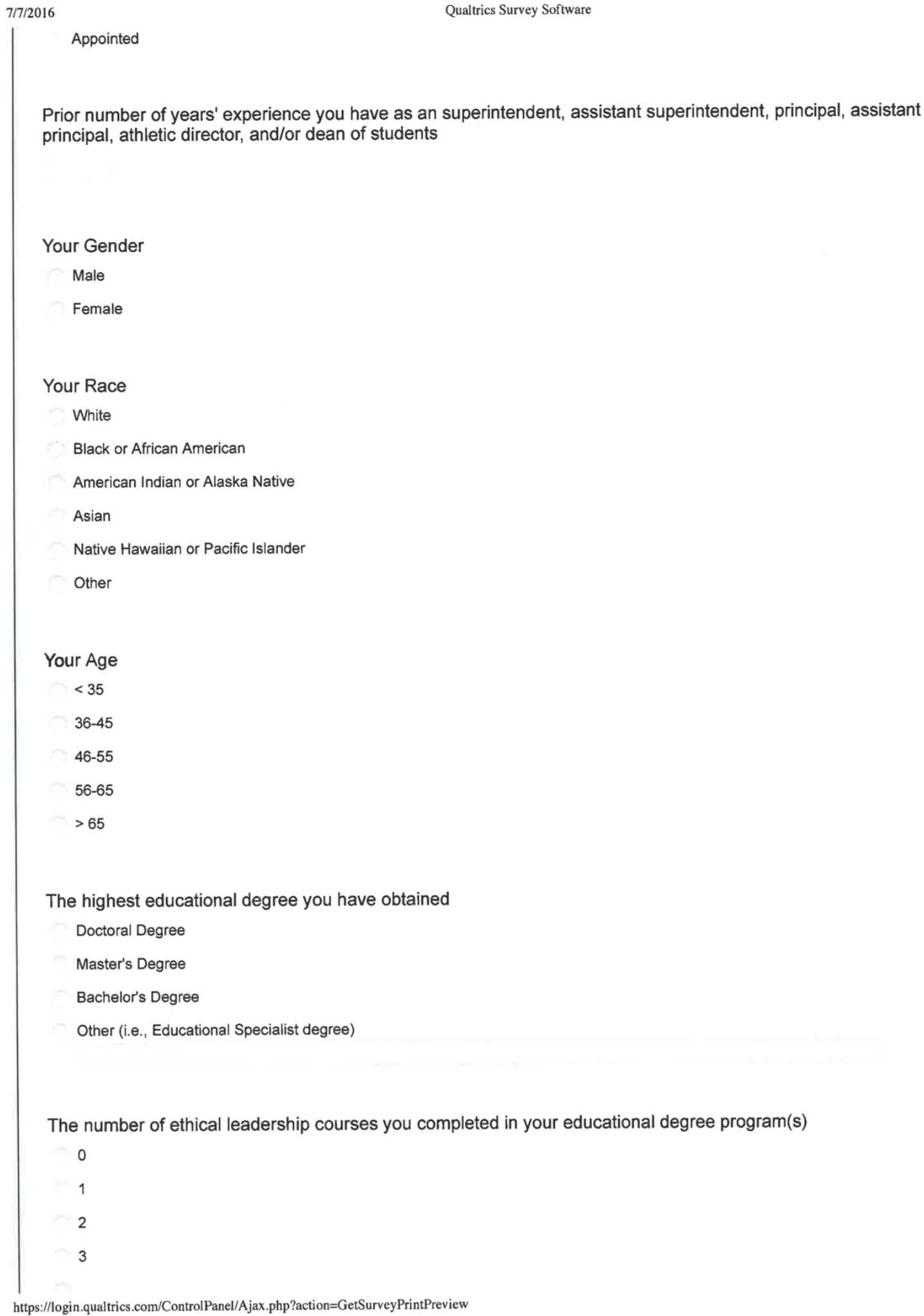

The number of ethical leadership courses you completed in your educational degree program(s)

$$
2
$$

https://login.qualtrics.com/ControlPanel/Ajax.php?action=GetSurveyPrintPreview 
Vol. 5, No. 3

$7 / 7 / 2016$

4

5 or more

Fowler et al.: An Investigation of State Superintendents...

Qualtrics Survey Software

The name of the educational institution where you completed your superintendent license program

If you completed and/or were part of any type of mentoring program/experience in your superintendent license program

Yes

No

If you completed and/or were part of any type of ethics training inservice and/or professional development outside of the required coursework for your superintendent license program

Yes

No

Please estimate the number of ethics training inservice and/or professional development hours that you completed outside of the required coursework for your superintendent license program

The professional organizations in which you have been actively involved in during the last five to ten years (please select all that apply)

American Association of School Administrators (AASA)

National School Boards Association (NSBA)

The Association of Supervision and Curriculum Development (ASCD)

National Association of State Boards of Education (NASBE)

Urban Superintendents Association of America (USAA)

National Association of State Administrators and Supervisors of Private Schools (NASASPS)

Other

The subject area(s) and grade levels (if any) in which you are licensed to teach

Section 2: State Education Characteristics

https://login.qualtrics.com/ControlPanel/Ajax.php?action=GetSurveyPrintPreview 
Please indicate

The total number of students in PreK-12 education in your state (state enrollment size)

The total number of superintendents in your state.

The total annual budget for education in your state

The majority of school district locale (i.e., Urban, Suburban, Rural) in your state.

The overall state rank (i.e., grade, score, and rank) of your state in PreK-12 educational setting in the United States according to the 2016 Education Week's Quality Counts report shown below. 
$7 / 7 / 2016$

Qualtrics Survey Software

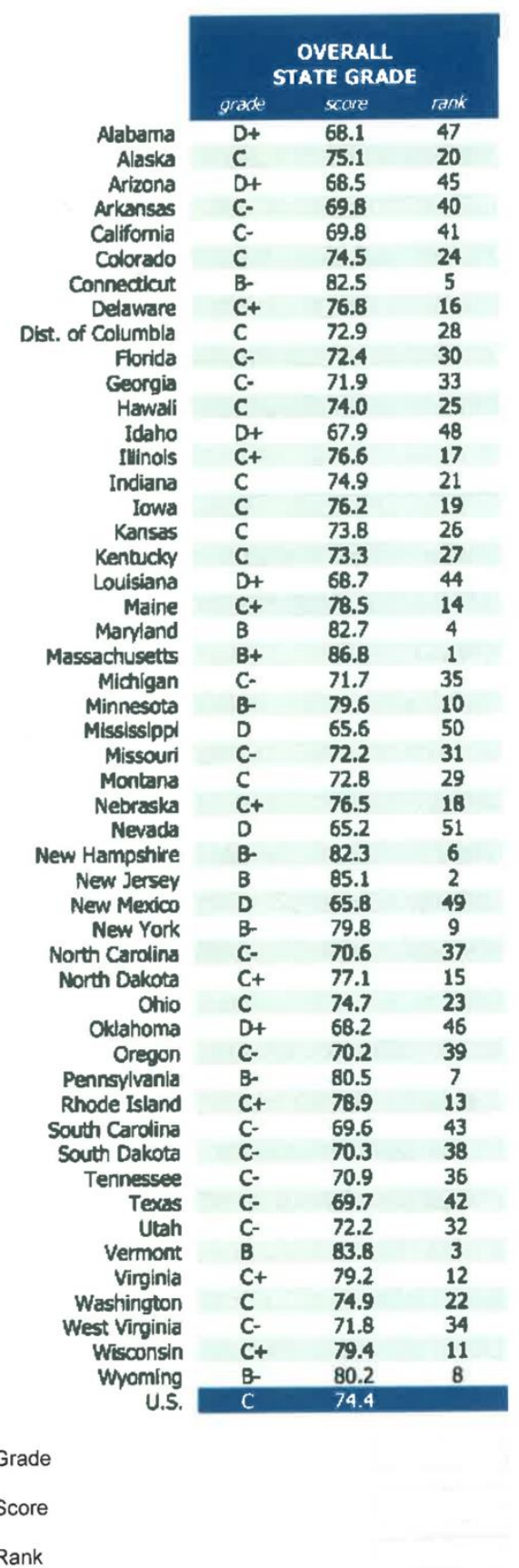

Section 3: Leadership Perspectives

For the following items, please respond by indicating the degree to which the statement reflects your own leadership. 
$7 / 7 / 2016$

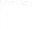

have to say

Disciplines employees who violate ethical standards

Conducts his/her personal life in an ethical manner

Has the best interests of employees in mind

Makes fair and balanced decisions

Can be trusted

Discusses ethics or values with employees

Sets an example of how to do things the right way in terms of ethics

Defines success not just by results, but also the way that they are obtained

When making decisions, asks "What is the right thing to do?"

\section{Section 4: Extended Response Questions}

Do you believe that your ethical leadership perspectives are affected by your state education characteristics (i.e., total students in your state, majority district locale in your state, state academic achievement, state education budget, etc.)?

Yes

No

Please explain and/or provide examples of why you believe that your ethical leadership perspectives are affected by your state education characteristics (i.e., total students in your state, majority district locale in your state, state academic achievement, state education budget, etc.)

What do you believe to be the most pressing issues facing state superintendents?

Do you believe that your ethical leadership perspectives are affected by your own leader demographics (i.e., https://login.qualtrics.com/ControlPanel/Ajax.php?action=GetSurveyPrintPreview 
age, years of experience, gender, race, etc.)?

Yes

No

Please explain and/or provide examples of why you believe that your ethical leadership perspectives are affected by your own leader demographics (i.e., age, years of experience, gender, race, etc.)

What do you believe most affects your ethical leadership perspectives in decision-making?

\section{Section 5: Personal Attitudes and Traits}

Listed below are a number of statements concerning personal attitudes and traits. Read each item and decide whether the statement is true or false as it pertains to you personally. It's best to go with your first judgment and not spend too long mulling over any one question.

I like to gossip at times.

There have been occasions when I took advantage of someone.

I'm always willing to admit it when I make a mistake.

I always try to practice what I preach.

I sometimes try to get even rather than forgive and forget.

At times I have really insisted on having things my own way.

There have been occasions when I felt like smashing things.

I never resent being asked to return a favor.

I have never been irked when people expressed ideas very different from my own.

I have never deliberately said something that hurt someone's feelings. 